\title{
'SPORTS VIOLENCE AS CRIMINAL ASSAULT: DEVELOPMENT OF THE DOCTRINE BY CANADIAN COURTS
}

Dramatic and numerous outbreaks of violence among athletes in the past twenty years have drawn public interest and concern in both the United States and Canada. ${ }^{1}$ The increase im sports violence was of public concern for several reasons; aside from the immediate injuries sustained

1. A recent dramatic incident of sports violence occurred during a November $20,1986 \mathrm{Na}$ tional Hockey League (NHL) game between the Boston Bruins and the Montreal Canadiens. Referees ejected eight players and assessed 124 minutes in penalties after a bench-clearing brawl halted play. The brawl spilled over into the corridor behind the Bruins bench, and erupted again on the rampway to the dressing room. N.Y. Times, Nov. 22, 1986, at 16, col. 1 . The NHL levied $\$ 14,000$ in fines against the players. USA Today, Jan. 7, 1987, § C, at 2, col. 3. The president of the Boston City Council reacted to the melee by proposing an ordinance requiring police officers to arrest players who interrupt games with fights. Id. See infra notes 2-3.

Notable incidents of sports violence in the United States from earlier years include the 1969 fight between NHL players Ted Green and Waync Maki, the striking of Dale Hackbart by Charles "Booby" Clark during a 1973 National Football League (NFL) game, a fight between Dave Forbes and Henry Boucha during a 1975 NHL game, and the striking of Rudy Tomjanovich by Kermit Washington during a 1979 National Basketball Association (NBA) game. These incidents stand out because of the prominence of the players involved and the seriousness of their injuries: the GreenMaki fight left Green close to death; Clark's blow caused a neck injury that ended Hackbart's career; Boucha needed twenty-five stitches to close a cut near his eye and surgery to repair a fracture in the floor of the right eye socket; and Tomjanovich suffered nose, jaw, and skull fractures, a brain concussion, and leakage of spinal fluid from the brain cavity. For more detailed descriptions of the facts of these cases, see J. BARnes, SPORTS AND THE LAW IN CANADA 105 (1983) (Maki-Green and ForbesBoucha); Note, Torts in Sports-Deterring Violence in Professional Athletics, 48 FordHAM L. REV. 764, 764 n.5, 765 n.9 (1980) (Clark-Hackbart, Washington-Tomjanovich) ; Note, Violence in Professional Sports, 1975 Wis. L. REV. 771, 771-72 (Boucha-Forbes).

Statistical compilations also indicate that the levels of sports violence were distressingly high during the years in question. The individual record for most penalties amassed by a professional hockey player in a single season increased from 153 minutes in the 1967-1968 season to 472 minutes in the 1974-1975 season. See Kennedy, Wanted: An End to Mayhem, SporTs Illustrated, Nov. 17,1975 , at 17,20. NHL officials assessed 22,329 minutes in penalties during the 1974-1975 season, an increase of $25 \%$ over the previous year. See Surface, Turn Off the Mayheml, READER's D1GEST, Mar. 1976, at 31, 32. The NHL Commissioner, who reported hearing at least ten discipline cases a week in 1975, and ten cases a season in which civil authorities might think a crime had been committed, called 1975 "our worst year ever for violence on the ice." See Kennedy, supra, at 18. The following season was even worse. See R. Horrow, Sports Violence: The InTERAction Between Private Lawmaking and the Criminal. Law 5 \& n.19 (1980).

The violence was not confined to professional hockey. The number of injuries that required a professional football player to miss two or more games increased 25\% from 1973 to 1974 . Yeager, The Savage State of Sports, Physician \& SPORTSMED., May 1977, at 96. A veteran NFL coach 
by the players involved, the violence arguably had a detrimental impact on both spectators, who were inspired to commit violent acts themselves, and aspiring young players, who were led to believe that aggressively violent behavior rather than skilled performance was the pathway to success. ${ }^{2}$

In response to this concern, a federal Sports Violence Act was introduced im the United States House of Representatives, first in 1980 and again with unchanged text in 1981. ${ }^{3}$ The proposed bill was intended to

identified the 1975 season as "the worst I've seen since I began coaching in the NFL." Hofeld, Athletes-Their Rights and Correlative Duties, 19 TRIAL LAw. GuIDE 383, 402 (1970).

Canadian arenas saw incidents of comparable violence during those years. During a HamiltonBramalea Ontario Hockey Association gaine in 1974, 189 penalty minutes were assessed, and five players and one team official were injured as a result of fighting and brawling. R. HorRow, supra, at $6 \&$ n.21. Fights during an NHL playoff game between the Philadelphia Flyers and the Toronto Maple Leafs in 1976 spread to involve spectators as well as players. J. BARNES, supra, at 100 . Also in 1976, Calgary player Rick Jodzio struck Marc Tardif of the Quebec Nordiques in the face with his stick, then punched him in the head, causing him to suffer a severe concussion. Id. at 105 .

2. See, e.g., Sprotzer, Violence in Professional Sports: A Need for Federal Regulation, CASE \& CoM., May-June 1981, at 3, 8 ("[V]iolent attitudes in children . . . are often learned froin professional athletes who frequently serve as role models for children's behavior on and off the field."). The major reason for Boston's proposed ordinance, see supra note 1 , was the impact that sports violence has on spectators. The preamble to the proposed ordinance stated:

Individuals who comprise the ranks of professional competition are accorded a great deal of respect and esteem .... . These individuals, in their highly visible roles have a major impact and influence on those who monitor their exploits .... Especially impressionable are children and teenagers, who often emulate the behavior of their favorite sport stars, perhaps not being fully cognizant of the fact that all conduct is not worthy of imitation [sic] .... Recent violent behavior committed by professional athletes while engaged in competition within the City of Boston has garnered inuch attention and has become the focus of public scrutiny .... Such athletieally spawned violence can result in a deleterious effeet on the youth of our city who regard many of these athletes as heroes.

Boston, Mass., Proposed Ordinance Subjecting Professional Athletes to Immediate Arrest (proposed by Councillor Bolling, Dec. 19, 1986; filed without further action, Feb. 27, 1987).

Other commentators have argued that spectators find healthy ventilation for their own violent emotions in watching violence on the playing field. From a public policy standpoint, the net result could be positive. See, e.g., Note, Violence in Professional Sports, 1975 WIS. L. REv. 771, 780 n.48 (spectators who must ordinarily inhibit their desires to react against pressures of urban life obtain vicarious satisfaction by observing and identifying with violence in sports); Comment, The Consent Defense: Sports, Violence, and the Criminal Law, 13 AM. CRIM. L. REv. 235, 242-43 n.53 (1975) (society as a whole benefits from organized sports because they provide both basic recreation and a means for spectators and participants to "rid[] themselves of potentially dangerous aggressive tendencies in a non-destructive manner"). An analogous argument for not prosecuting hockey players for ordinary fist fights is that such fights serve as an escape valve for players' frustrations; if this ineans of release were unavailable, players might resort to attacks using sticks or other equipment. J. BARNES, supra note 1, at 122 .

3. The bill was first introduced as H.R. 7903, 96th Cong., 2d Sess., 126 CoNG. Rec. 20,890 (1980). It was reintroduced in 1981 as H.R. 2263, 97th Cong., lst Sess., 127 CoNG. REC. 3480 (1981). Neither bill was reported out of committee.

Some state legislation deals specifically with sports violence. See, e.g., IowA CoDE ANN. $\S 708.1$ (1979) (reasonably foreseeable injuries received by voluntary participants in sports are not considered criminal assault); OKLA. STAT. ANN. tit. 21, $\$ 650.1$ (West 1983) (defining liability for "assault and battery upon the person of a referee, umpire, timekeeper, coach, player, participant, 
deter and punish episodes of violence in professional sports by iniposing criminal penalties; it would have made the use of unreasonably violent force having no reasonable relationship to the competitive goals of the sport a felony punishable by up to a year in prison and a $\$ 5,000$ fine. ${ }^{4}$ Although the drafters expected prosecutions under the Act to be rare, some contended that having the federal government take a stand on the issue of sports violence would have a strong syinbolic effect. ${ }^{5}$

Proponents of the Act said that federal legislation to control violence in professional sports was necessary because existing meclianisms for curbing violence had been ineffective. League self-regulation liad not satisfactorily deterred excessively violent acts, ${ }^{6}$ and state and local laws

official, sports reporter or any person having authority in connection with any amateur or professional athletic contest"); $c f$. Carroll v. State, 620 P.2d 416, 417-18 (Okla. Crim. App. 1980) (upholding section 650.1 against a constitutional challenge on grounds of vagueness).

After a recent brawl during a Boston Bruins hockey game, see supra note 1, the president of the Boston City Council proposed an ordinance requiring police officers to arrest players who interrupt games with fights. The proposed ordinance provided:

Section 2. Any professional athlete engaged in competition within the City of Boston, shall be subject to immediate arrest by any member or inembers of the Boston Police Department upon the commission of any violent act during said competition.

Boston, Mass., Proposed Ordinance Subjecting Professional Athletes to 1mmediate Arrest, $\$ 2$ (proposed by Councillor Bolling, Dec. 19, 1986; filed without further action, Feb. 27, 1987). "Violent act" included both assault and battery. See id. § 1(b) ("violent act" includes all "crimes against persons"); see also MASS. GEN. L. ch. 265, § 13A (1980) (assault and battery are "crimes against persons"). Section 3 of the proposed ordinance expressly excluded prize fighting from its reach.

4. The Act read, in relevant part:

(a) Whoever, as a player in a professional sports event, knowingly uses excessive physical force and thereby causes a risk of significant bodily injury to another person involved in that event shall be fined not more than $\$ 5,000$ or imprisoned not more than one year, or both.

(b) As used in this section, the term-

(1) "excessive physical force" means physical force that-

(A) has no reasonable relationship to the competitive goals of the sport;

(B) is unreasonably violent; and

(C) could not be reasonably foreseen, or was not consented to, by the injured person, as a nornal hazard of such person's involvement in such sports event; and

(2) "professional sports event" means a paid-admission contest, in or affecting interstate or foreign commerce, of players paid for their participation.

H.R. 7903, 96th Cong., 2d Sess. \$115 (1980).

5. See Engler, Kill 'Em/ Sports Violence and the Law, UpDate on LAw-Related EdUC., Spring 1983, at 3,63.

6. Professional sports leagues responded to concern that the level of violence in sports was too high by passing new rules and revising old ones. Between 1962 and 1980, the NFL made nearly 100 rule changes aimed at promoting safety and discouraging violence. Slonim, Goal of Crime Bill to Curb Sports Violence, 66 A.B.A. J. 1188, 1189 (1980). 1n addition to specific rule changes, the NFL issued a general warning in 1978 that " 'unbridled violence' designed to injure or intimidate opponents, would lead to 'serious league discipline.' "Id. at 1189. The NBA issued a similar directive. Id. But several problems with the deterrent effect of league-innosed sanctions remain. In light of the salaries and bonuses many athletes receive, even seemingly hefty fines can be incurred with little concern. Moreover, disciplinary fines imposed on players by leagues are often paid by their teams. See Reaves, Cleaning Up Sports, 70 A.B.A. J. 32, 32 (1984). 
were not being enforced. ${ }^{7}$ It was beheved that professional athletes could realistically be expected to conform their behavior to a uniform national standard. 8

Opponents of the Act presented three principal arguments. Representatives of professional sports leagues vigorously argued that league self-regulation was the best method for reducing violence in sports. ${ }^{9}$ Some congressmen viewed the Act as frivolous im light of more pressing demands on the legislature's calendar. ${ }^{10}$ Finally, there was a concern that passage of the Act would allow federal intervention im an area that could be handled adequately by state law. ${ }^{11}$

The question whether existing state civil and criminal laws were adequate to allow effective control of sports violence could only be answered on a theoretical level when the Act was under consideration in 1980 and 1981. The 1970's saw an expansion in the use of tort law by plamtiffs seeking to recover for injuries sustained on playing fields, ${ }^{12}$ but

7. See Sprotzer, supra note 2 , at 6 .

8. Id.

9. See The Sports Violence Act of 1980: Hearings on H.R. 7903 Before the Subcomm. on Crime of the House Comm. on the Judiciary, 96th Cong., 2d Sess. (1980) (statements by John A. Ziegler, Jr., President of the NHL; Bowie W. Kuhn, Commissioner of Major League Baseball; Phillip A. Woosnam, Commissioner of the North American Soccer League; Lawrence F. O'Brien, Commissioner of the NBA). For a discussion of the advantages and disadvantages of making league selfregulation the sole mechanism for controlling sports violence, see Comment, A Proposed Legislative Solution to the Problem of Violent Acts by Participants During Professional Sporting Events: The Sports Violence Act of 1980, 7 U. DAYTON L. REV. 91, 93-95 (1981).

10. See Engler, supra note 5, at 63; see also Sprotzer, supra note 2, at 8 (resistance to the Act reflected a more general public concern with government encroachment into too many aspects of society).

11. See Engler, supra note 5, at 63 .

12. For a leading case illustrating the recent expansion of tort law, see Nabozny v. Barnhill, 31 IIl. App. 3d 212, 215, 334 N.E.2d 259, 260-61 (1975) (participant in organized athletic competition has legal duty to other players to refrain from conduct proscribed by rules designed to protect players from serious injury). Since Nabozny, several other courts have held that recovery in tort for nonintentionally inflicted sports injuries may lie where there is a showing of recklessness or willful misconduct, although negligence may not provide a sufficient basis. See, e.g., Oswald v. Township High School Dist., 84 Ill. App. 3d 723, 727, 406 N.E.2d 157, 159-60 (1980) (action seeking recovery for personal injuries suffered by high school student in course of physical education class basketball game dismissed for failure to state a claim; complaint charged injuring student with ordinary negligence rather than willfulness or reckless disregard of safety); Ross v. Clouser, 637 S.W.2d 11, 13-14 (Mo. 1982) (en banc) (case submitted to jury on negligence theory remanded for retrial with instructions that case be submitted solely on recklessness theory); Kabella v. Bouschelle, 100 N.M. 461, 465, 672 P.2d 290, 294 (1983) (summary judgment for defendant properly granted where plaintiff injured in loosely organized neighborhood football game had based complaint on negligence theory rather than intentional tort or reckless conduct); see also Note, Tort Liability for Players in Contact Sports, 45 UMKC L. REV. 119 (1976) (evaluating Nabozny); Annotation, Liability of Participant in Team Athletic Competition for Injury to or Death of Another Participant, 77 A.L.R.3d 1300 (1977).

Despite the problem of opening court doors to a large number of new and difficult cases, the United States Court of Appeals for the Tenth Circuit has held that federal courts are not justified in 
so few criminal prosecutions were brought as a result of sports violence ${ }^{13}$ that the efficacy of existing doctrines remained untested. ${ }^{14}$

In contrast, Canadian prosecutors have used the criminal law much more frequently against athletes accused of violently injuring fellow players. There have been more than one hundred criminal convictions for offenses involving player-player violence in the last fifteen years, and there are at least ten reported cases indicating lines of doctrinal development over that period. ${ }^{15}$ Thus, when the Law Reform Commission of Canada issued its working paper on Assault in 1984,16 it had the benefit of hindsight in evaluating the efficacy with which existing doctrines could be used in prosecuting incidents of sports violence. The Cominission's assessment was that no changes in the existing formulation of the relevant statutes were necessary. ${ }^{17}$

refusing to accept jurisdiction of tort cases arising out of disputes in professional football games. See Hackbart v. Cincinnati Bengals, 601 F.2d 516, 522 (10th Cir.), cert. denied, 444 U.S. 931 (1979).

13. See People v. Jones, 37 III. App. 3d 879, 884, 346 N.E.2d 389, 392 (1976) (affirming jury verdict of guilty in trial of high school student for battery; accused had punched opponent in nose at close of touch football game); People v. Freer, 86 Misc. 2d 280, 284, 381 N.Y.S.2d 976, 979 (Dist. Ct. 1976) (football player convicted of third-degree assault for punching opponent in eye after play had stopped).

In a widely discussed case involving professional players, Dave Forbes of the Boston Bruins was prosecuted on a charge of aggravated assault with a dangerous weapon for striking Henry Boucha of the Minnesota North Stars with his hockey stick. State v. Forbes, No. 63,280 (Minn. Dist. Ct., 4th Jud. Dist., judgment of mistrial entered, Aug. 12, 1975). The jury was unable to agree on a verdiet, and the prosecutor decided not to reprosecute. For an account of the trial coauthored by the county attorney who prosecuted Forbes, see Flakne \& Caplan, Sports Violence and the Prosecution, Trial, Jan. 1977, at 33, 34.

14. Although few criminal prosecutions of violence in sports have been brought in the United States, there are strong arguments supporting the incrcased use of the criminal law to curb sports violence. If the state has an interest in decreasing the incidence of sports violence, it should prosecute violations. Use of the criminal law could have significant deterrent effect because of the severity of sanctions that could be imposed. Moreover, the similarities between existing criininal offenses and many sports violence offenses make it appropriate that the state prosecute such offenses.

There are, however, arguments against the increased use of the criminal law in this context. Jurors may be biased in favor of home-team players. Prosecutors may bring charges against only visiting-team players. Not all offenses could practicably be prosecuted, and other prosecutions already compete for the limited resources of the criminal justice system. Finally, although the severity of criminal sanctions may provide a desirable deterrent effeet, imposing such sanctions against a player whose conduct has thus far been accepted as within the spirit of the game nay seein unduly harsh.

15. Ten is a conservative figure. Because courts have been reluctant to draw bright lines in sports violence cases, cases that are somewhat off point are nonetheless used in judicial analysis. Two such cases that are frequently cited, although they do not involve player-player violence during a game, are La Reine c. Prénoveau, 1971 R.L. 21 (Que. G.S.P. 1969), which involved an assault by a player on a referee, and Sinithers v. The Queen, [1978] 75 D.L.R. 3d 321 (Can. 1977), which involved one hockey player killing another after the conelusion of the gaine.

16. Law Reform Commission of Canada, Working Paper No. 38, Assault (1984).

17. The Commission stated:

[W] consider the solution to this social problem of sports violence to lie in essence outside the redrafting of our present assault provisions. It lies rather in a greater police and 
Because instances of sports violence in the United States would probably be prosecuted, as in Canada, as a form of assault, ${ }^{18}$ and because the definitions of the relevant offenses in the United States and Canada are similar in their essential features, the success of Canadian courts in applying existing statutes to sports violence offenses strongly suggests that existing criminal laws can be apphed effectively in similar cases in the United States. This note will present the historical background against which the recent increase in Canadian criminal prosecutions of sports violence occurred. ${ }^{19}$ It will then discuss the current state of the Canadian law of assault as it relates to sports violence, einphasizing particularly the courts' treatnient of the consent defense. ${ }^{20}$ It will further review and analyze the Canadian courts' consideration of various brightline distinctions potentially useful in defining when sports violence offenses should be treated differently fronı similarly assaultive behavior outside the sports context. ${ }^{21}$ This analysis will demonstrate that although Canadian courts have not definitively resolved all issues related to criminal prosecutions for sports violence, these issues are amenable to effective judicial resolution. The note concludes that American courts could adopt the Canadian approach and thus obviate the need for additional legislation.

\section{HistoricAl BACKGROUND}

Although the number of reported criminal cases involving sports violence is far greater in Canada than in the United States, their nuinber is still quite sinall. This is in part because the Canadian criminal justice systein has only recently conie to be seen as an appropriate tool for containing sports violence. ${ }^{22}$ Two hockey gaines have been seninally impor-

prosecutorial vigilance, in stricter enforcement of existing law and in less judicial tolerance and leniency for "sports assaults."

Id. at 35 .

18. "Assault" is used here in its looser sense to encompass the separate common law misdemeanors of assault and battery. See W. LAFAVE \& A. SCOTT, HANDBOOK ON CRIMINAL LAW $\S 80$ (1972). In many American jurisdictions, prosecution would be for battery rather than assault. See Note, Violence in Professional Sports, 1975 W1S. L. REv. 771, 773 ("[M]ost sports fights would seem to come within the basic definition of criminal battery."); see also People v. Jones, 37 Ill. App. 3d 879,346 N.E.2d 389 (1976) (fight between high school football players; conviction on charge of battery). But see State v. Forbes, No. 63280 (Minn. Dist. Ct., 4th Jud. Dist., judgment of mistrial entered, Aug. 12, 1975) (prosecution for aggravated assault with a dangerous weapon); People v. Freer, 86 Misc. 2d 280, 284, 381 N.Y.S.2d 976, 979 (Dist. Ct. 1976) (fight between football players; conviction on charge of third-degree assault).

19. See infra notes 22-35 and accompanying text.

20. See infra notes $36-102$ and accompanying text.

21. See infra notes 103-34 and accompanying text.

22. For a discussion of Canadian criminal prosecutions for sports violence during the first quarter of the twentieth century, see J. BARNES, supra note 1, at 108-12, 115. 
tant to the modern Canadian cases involving criminal prosecutions for sports violence. A 1969 NHL exhibition game involved a fight between Ted Green of the Boston Bruins and Wayne Maki of the St. Louis Blues that led to prosecutions of both players. Both players were prosecuted under different sections of the Criminal Code of Canada, ${ }^{23}$ but neither trial resulted in a conviction. ${ }^{24}$ Nonetheless, Regina v. Green and Regina v. Maki have been important as precedents partly because they were cases of first impression and partly because the courts that decided them took seriously their roles as estabishers of new principles. ${ }^{25}$ In the second historically important game, the 1974 Hamilton-Bramalea Hockey Association game, brawling on the ice led to brawling among spectators. No one was prosecuted, but the violence led the Canadian government to coinmission Ontario attorney William R. McMurtry to produce a study on hockey violence. ${ }^{26}$ Shortly thereafter, Roy McMurtry, Attorney General of Ontario, called for more active prosecution of sports violence offenses. ${ }^{27}$ The significant increase in the number of sports violence prosecutions over the last ten years can be largely attributed to this governmental encouragement. 28

23. Green was charged with common assault. Regina v. Green, [1971] I O.R. 591, 594 (Ont. Prov. Ct. 1970). Maki was charged with assault causing bodily harm. Regina v. Maki, [1970] 3 O.R. 780, 780 (Ont. Prov. Ct. 1970).

24. Green, [1971] I O.R. at 597; Maki, [1970] 3 O.R. at 782.

25. That the judges approached their tasks with particular consciousness of the importance of the doctrines they were articulating is evident from the extensive dicta contained in the opinions. See, e.g., Green, [1971] 1 O.R. at 597 (stating that it is difficult to envision incidents during an NHL game that could support a conviction of common assault as opposed to assault causing actual bodily harm); Maki, [1970] 3 O.R. at 783 (stating that the adoption of certain principles would benefit players, the public, and young aspiring athletes who model themselves on professionals).

26. MCMURTRY, INVESTIGATION AND INQUIRY INTO VIOLENCE IN AMATEUR HOCKEY (TOronto: Ministry of Community and Social Services, 1974). A similar study of hockey violence in Quebec was also produced. NERON, RAPPORT FINAL DU COMITÉ D'ÉTUDE SUR LA VIOLENCE AU HOCKEY AMATEUR AU QUEBEC (Gouvernement du Québec, Haut-commissariat à la jeunesse, aux loisirs et aux sports, 1977).

27. J. BARNES, supra note 1, at 126-27. McMurtry particularly urged more rigorous enforcement of the sections of the Criminal Code governing assaults resulting in serious bodily injury. Hechter, The Criminal Law and Violence in Sports, 19 CRIM. L.Q. 425, 428 \& n.14 (1977).

28. During the 1975-1976 hockey season, approximately twice as many sports prosecutions were brought as in the preceding two seasons combined. J. BARNES, supra note 1, at 127. More of the reported criminal cases involving sports violence have been brought in Ontario than in any other province. Six of the eleven reported cases were brought in Ontario. Regina v. Watson, 26 C.C.C.2d 150 (Ont. Prov. Ct. 1975); Regina v. Leyte, 13 C.C.C.2d 458 (Ont. Prov. Ct. 1973); Regina v. Green, [1971] 1 O.R. 591 (Ont. Prov. Ct. 1970); Regina v. Maki, [1970] 3 O.R. 780 (Ont. Prov. Ct. 1970); Regina v. St. Croix, 47 C.C.C.2d 122 (Ont. Co. Ct. 1979); Regina v. Maloney, 28 C.C.C.2d 323 (Ont. G.S.P. 1976). Only St. Croix, Maloney, and Watson postdate McMurtry's recommendation for increased prosecution, discussed supra at text accompanying note 27. Smithers v. The Queen, [1978] 1 S.C.R. 506 (Can. 1977) (manslaughter conviction of hockey player who killed opponent after game), also originated in Ontario. Two of the reported cases are from Quebec. See R. v. Coté, 22 C.R.3d 97 (Que. Prov. Ct. 1981); Re Duchesneau, [1979] 7 C.R.3d 70 (Que. Youth Trib. 1978). La Reine c. 
In assessing the doctrines developed by the courts, it is important to remember that trial courts have rendered all reported Canadian decisions. ${ }^{29}$ Many of the decisions were delivered orally ${ }^{30}$ and do not reflect the precision of organization and terminology one might expect in written appellate decisions. The courts rarely cite precedent; when they do, lowever, they rely on $M a k i$ and Green and overlook later cases.

Sports violence offenses may be prosecuted as common assault. ${ }^{31}$ Section 244(a) of the Criminal Code of Canada contains the statutory definition of common assault: "A person commits an assault when ... without the consent of anotlier person, he apphies force intentionally to that other person, directly or indirectly." 32 There have been no reported convictions in cases where the originally charged offense was common assault. There have, however, been several convictions of common assault as a lesser included offense. ${ }^{33}$ More often, sports violence offenses

Prénoveau, 1971 R.L. 21 (Que. G.S.P.) (assault by a player on a referee), was also a Quebec case. There is one reported case from British Columbia, Regina v. Henderson, [1976] 5 W.W.R. 119 (B.C. Co. Ct. 1976), and one from Saskatchewan, Regina v. Gray, [1981] 6 W.W.R. 654 (Sask. Prov. Ct. 1981). An unreported case decided by an appellate court in Saskatechewan is discussed in Brent, Hockey Violence-Regina v. Langton-A Case Note, 32 C.R. (n.s.) 121 (1976).

The reporters contain two cases arising from the November 1975 altercation between Brian Glennie and Daniel Maloney. A portion of the charge to the jury in Maloney's trial for assault causing bodily harm is published in Maloney, 28 C.C.C. $2 \mathrm{~d}$ at 323 . Another portion of the same case involves the admissibility of videotape evidence and is published in Regina v. Maloney (No. 2), 29 C.C.C.2d 431 (Ont. G.S.P. 1976). Although the issues discussed in the latter opinion are not relevant to this note, that opinion provides some description of the factual background surrounding the alleged assault that is not available in the reported part of the assault trial itself.

29. Regina v. Langton, an unreported case discussed in Brent, supra note 28, was decided by the Court of Appeals of Saskatchewan. The Supreme Court of Canada decided Smithers v. The Queen, [1978] 75 D.L.R.3d 321 (Can. 1977), see supra note 15, but the assault there occurred after the game was over, so the issues involved were different.

30. See, e.g., Watson, 26 C.C.C.2d at 151; Green, [1971] 1 O.R. at 591.

31. See, e.g., Green, [1971] 1 O.R. at 594.

32. CRIMinal CoDE, R.S.C. 1970, c. C-34, § 244 [re-en. 1980-81-82, c. 125, § 19]. The Code uses "assault" rather than "common assault" in section 244, but "common assault" is frequently used as a synonym in judicial opinions. See, e.g., Green, [1971] 1 O.R. at 597. Green was brought under a predecessor to section 244 that does not differ from section 244 as far as sports violence prosecutions are concerned. See id. at 594.

33. The jury in Maloney was instructed to consider common assault as a lesser included offense in that prosecution for assault causing bodily harm. See Regina v. Maloney, 28 C.C.C.2d at 323, 325, 329 (Ont. G.S.P. 1976). The defendant in Duchesneau was charged with manslaughter. See Re Duchesneau, [1979] 7 C.R.3d 70, 71 (Que. Youth Trib. 1978). The court considered and rejected the possibility of a conviction for aggravated assault, $i d$. at 81 , but handed down a conviction for common assault as a lesser included offense. Id. at 84 .

Other charges can be brought as well. During a play-off game in Toronto in 1976, two Philadelphia Flyers players were charged with possession of a dangerous weapon-a hockey stick-for a purpose dangerous to the public peace. See J. BARNES, supra note 1, at 100-01. The Crown eventually dropped the charge against one player and stayed proceedings against the other. Id. at 101 . Because conviction for this offense requires proof that the accused had the intention of using the 
are prosecuted as assault causing bodily harm. ${ }^{34}$ The assailant can be convicted of assault causing bodily harm only if the injury inflicted upon the complainant interferes with the complainant's health or coinfort and is more than merely transient or trifling in nature. ${ }^{35}$

\section{The Consent Defense}

The major analytic problem courts have faced in prosecutions for sports violence offenses has been the effect of the consent defense. ${ }^{36} \mathrm{Be}$ cause the Canadian statutory definition of assault specifies that the intentional apphication of force to the person of another inust be without that person's consent, a finding that there was consent negates a necessary element of the offense. ${ }^{37}$ Three issues involved in the consent defense have arisen in the reported cases: consent implied by participation in the gaine, ${ }^{38}$ consent implied by specific acts during the game, ${ }^{39}$ and public policy limitations on the ability to consent. ${ }^{40}$

weapon for a dangerous purpose and because hockey players generally carry their sticks onto the ice for other reasons, such prosecutions are unlikely to result in convictions.

34. See, e.g., Regina v. Henderson, [1976] 5 W.W.R. 119, 120 (B.C. Co. Ct. 1976); Regina v. Watson, 26 C.C.C.2d 150, 151 (Ont. Prov. Ct. 1975); Regina v. Leyte, 13 C.C.C.2d 458, 458 (Ont. Prov. Ct. 1973); Regina v. Maki, [1970] 3 O.R. 780, 780 (Ont. Prov. Ct. 1970); Regina v. St. Croix, 47 C.C.C.2d 122, 123 (Ont. Co. Ct. 1979); Maloney, 28 C.C.C.2d at 329 (charging the jury that one of the verdicts it might bring in was "guilty as charged, that is guilty of assault causing bodily harm"); R. v. Coté, 22 C.R.3d 97, 98 (Que. Prov. Ct. 1981); Regina v. Langton, (Sask. C.A. Oct. 2, 1974), discussed in Brent, supra note 28, at 122; R. v. Gray, [19811 6 W.W.R. 654, 655 (Sask. Prov. Ct. 1981).

35. CRiminal Code, R.S.C. 1970, c. C-34, § 245.1 [re-en. 1980-81-82, c. 125, § 19].

36. The consent defense is of major importance in the United States as well. See, e.g., Horrow, Violence in Professional Sports: Is It Part of the Game?, 9 J. Legrs. 1, 9 (1982) ("A defendant's most productive defense is 'athletes willingly consent to all contact incident to the game." "). For additional discussion of sports violence and the consent defense, see Note, Consent in Criminal Law: Violence in Sports, 75 Mrch. L. Rev. 148 (1976); Note, Criminal Law: Consent as a Defense to Criminal Battery-The Problem of Athletic Contests, 28 OKLA. L. REV. 840 (1975); Comment, The Consent Defense: Sports, Violence, and the Criminal Law, 13 AM. CRIM. L. REV. 235 (1975).

37. Under certain circumstances, the fact that consent has been given is no defense. See CrimiNAL CODE, R.S.C. 1970, c. C-34, § 244(3) [re-en. 1980-81-82, c. 125, § 19] (no consent where complainant submits or does not resist because of the application of force, threats, or fear of the application of force, fraud, or the exercise of authority). None of these possible negations of the consent defense have arisen in any of the cases involving sports violence.

38. See infra notes $42-87$ and accompanying text.

39. See infra notes 88-94 and accompanying text.

40. See infra notes 95.102 and accompanying text. A fourth issue-whether there was express consent to an assault-has arisen in several cases, but it has always been answered in the negative without extended discussion. See, e.g., Watson, 26 C.C.C.2d at 156-57; Gray, [1981] 6 W.W.R. at 660 . 


\section{A. Consent Implied by Participation in the Game.}

The extent to which players consent to an assault merely by participating in an organized athletic contest has been the thorniest issue confronting Canadian courts. The courts have articulated several general standards, defining both consented-to and unconsented-to conduct. The general standards are broad and apply to sports of all kinds. In addition to these general standards, the courts have developed some unarticulated principles for distimguishing between conduct subject to criminal prosecution and conduct not subject to criminal prosecution. The unarticulated principles are more fact-specific; they have developed as courts ruled on prosecutions arising out of hockey games, and their relevance is limited to that sport. ${ }^{41}$

\section{Scope of Implied Consent: General Standards.}

a. Conduct consented to by game participants. In attempting to provide a general definition of nonprosecutable conduct, courts look inost often to the relationship between the alleged assault and the actions necessarily involved in playing the game. Courts have articulated three tests, each phrased shightly differently, to describe permissible player conduct. Players are presumed to consent to conduct "incidental to the sport," 42 conduct "inherent in and reasonably incidental to the normal playing of the gaine," 43 and conduct "closely related to the play." 44 The three different tests essentially create a standard that both recognizes the primacy of actions that are an intrinsic part of the sport and adds a inargin of grace around them to include actions closely connected to playing the game. The principle is unassailable, but it has two drawbacks in practice. First, courts' ideas about what is incidental to the game are hard to predict. Second, the tests offer hittle practical guidance to players because the tests are not accoinpanied by useful examples of conduct that meet their definitions.

One judge, professing to follow the incidental-to-the-sport standard, went on to declare: "I have no doubt whatsoever that fighting is part of the game of hockey." 45 Thus, in this judge's view, fights between two

41. Very few of the Canadian sports violence cases have arisen outside the hockey context. See, e.g., Regina v. Leyte, 13 C.C.C.2d 458 (Ont. Prov. Ct. 1973) (school handball game).

42. Regina v. Henderson, [1976] 5 W.W.R. 119, 123 (B.C. Co. Ct. 1976).

43. Regina v. Maloney, 28 C.C.C.2d 323, 326 (Ont. G.S.P. 1976). See also R. v. Gray, [1981] 6 W.IV.R. 654, 661 (Sask. Prov. Ct. 1981) (applying the Maloney standard).

44. Leyte, 13 C.C.C.2d at 459.

45. Henderson, [1976] 5 W.W.R. at 123. The court's statement that fighting was part of the game should be understood in the context of the accused player's contention that "fighting was part of the game since it had started and nothing was ever said about it before." Id. at 122. 
voluntarily involved players are "incidental to the game" 46 of hockey, and criminal actions against the participants are inappropriate. This definition of "incidental to the game" is questionable. If the purpose of the game of hockey is to score more goals than the opposing team, fighting serves the purpose only msofar as it intimidates the opposition from mounting a vigorous defense or rattles them so that they fail to score. Defining "incidental" broadly enough to include gratuitous fighting makes a mockery of the entire test.

Aside from the contested issues of fighting, several courts have given examples of conduct incidental to the game. In one case, the court mentioned "body contacts [and] boardings" as conduct to which consent is assumed. ${ }^{47}$ In another, the court described the kinds of risks that a player presumably would not consent to assume:

For example, I would not expect, where two players are utilizing their fists in an altercation, that one of the players would end up with an incision across his face which would require 75 stitches to close. Or what of the situation where, during an altercation between two players using their fists, one of the players continues to puinmel the other, who at that tine is either unconscious or rendered helpless? Or what of the situation where one of the players involves [sic] the use of an instrument such as a hockey stick? Or what of the situation where one of the players uses the ice in such a way that the opposing player's head comes into frequent and violent contact with it? Surely these are not the risks which the injured player assuined by participation in the sport. ${ }^{48}$

Most of these illustrative examples are unobjectionable, ${ }^{49}$ but they are not very helpful because they refer to extreme instances of conduct, leaving a vast uncharted middle ground.

46. Id. at 125 .

47. Maloney, 28 C.C.C.2d at 328.

48. Henderson, [1976] 5 W.W.R. at 124. It is not entirely clear which of two defenses, consent or assumption of risk, the court is analyzing here. In many American jurisdictions, assumption of risk is not a defense to criminal charges. See, e.g., Flakne \& Caplan, supra note 13, at 34 ("The defense [in the Minnesota trial State v. Forbes] had requested and was denied an instruction on the assumption of risk by virtue of its sole applicability to civil law."). Many of the Canadian courts, however, have used assumption of the risk and consent interchangeably in sports violence cases. See, e.g., Regina v. Maki, [1970] 3 O.R. 780, 783 (Ont. Prov. Ct. 1970) ("Thus all players, when they step onto a playing field or ice surface, assume certain risks and hazards of the sport, and in most cases the defence of consent ... would be applicable."').

49. There are, however, minor problems with two of these four examples of unconsented-to conduct. The first example defines the undesirable conduct in terms of results. It would be more useful to formulate the definition in terms of conduct. If athletes know that they will incur liability if they engage in certain forms of conduct, they can avoid doing so; conforming behavior to norms that specify only the results to be avoided is more difficult. The third example is vague. Not all uses of the stick are equally culpable. A reading that emphasizes the words "use" and "instrument" may salvage the example by emphasizing the player's intent purposefully to use the stick in the altercation, but this interpretation is strained. 
Several courts have added further tests to this core concept of conduct incidental to the sport. One variation is a two-part conjunctive test: in addition to being incidental to the sport, conduct must be "within the bounds of fair play" before consent will be assumed. ${ }^{\text {so }}$ Adding fair play as a criterion does not significantly increase the utility of the test, because fair play is an elusive concept. Furthermore, the examples given by the court to illustrate conduct prosecutable under this test ${ }^{51}$ all mvolve conduct not incidental to play, so no narrowing effect of the additional factor is evident. But introducing fair play does have a narrowing impact if fighting is considered mcidental to play: under the two-part test only unarmed fighting, where the players are restricted to using their hands alone, is considered within the bounds of fair play. ${ }^{52}$

In another variation, one court has said that players consent to conduct that is "instinctive and closely related to the play." 53 This two-part test merely incorporates the basic idea that criminal liability requires criminal imtent, and if conduct is truly instmctive, then there is no such intent. 54

b. Conduct not consented to by game participants. The standard most frequently used to define tlie limits on players' consent is the test originally articulated in a 1965 tort case, Agar v. Canning:"55 "[I]njuries inflicted in circumstances whicl show a definite resolve to cause serious injury to another, even when there is provocation and in the heat of the game, should not fall within the scope of the implied consent." 56 Maki ${ }^{57}$ quoted this test with approval, and two other courts in criminal cases have subsequently adopted it. ${ }^{58}$ Althougl the standard has the virtue that all actions encompassed by it rightfully should be criminally actionable, it has the drawback of being severely underinclusive.

50. Henderson, [1976] 5 W.W.R. at 124.

51. See supra text accoinpanying note 48 .

52. Henderson, [1976] 5 W.W.R. at 124.

53. Regina v. Leyte, 13 C.C.C.2d 458, 459 (Ont. Prov. Ct. 1973).

54. For other formulations dealing with the absence of intent, see R. v. Coté, 22 C.R.3d 97, 101 (Que. Prov. Ct. 1981) ("accidental"), and Agar v. Canning, 54 W.W.R. 302, 304 (Man. Q.B. 1965) ("unintentional"), aff'd, 55 W.W.R. 384 (Man. C.A. 1966).

55. 54 W.W.R. 302 (Man. Q.B. 1965), aff'd, 55 W.W.R. 384 (Man. C.A. 1966).

56. Id. at 304 .

57. Regina v. Maki, [1970] 3 O.R. 780, 783 (Ont. Prov. Ct. 1970).

58. Regina v. Henderson, [1976] 5 W.W.R. 119, 124 (B.C. Co. Ct. 1976) (applying the standard in a slightly modified version: "conduct which shows a deliberate purpose to inflict injury"); Regina v. Maloney, 28 C.C.C.2d 323, 327 (Ont. G.S.P. 1976) (quoting Agar). 
2. Scope of Implied Consent: Unarticulated Principles.

a. Players' consent to minimal contacts. Participants in contact sports are deemed to consent to various minor body contacts. The factors to which courts look include the frequency of the type of contact in the sport, the level of force involved, and the degree of injury inflicted.

The court in Regina v. Green ${ }^{59}$ held that a punch or blow with the gloved hand to an opponent's face was not an assault because players assuuned the risk of such blows. The player who was struck testified that he had been struck this way hundreds of times, ${ }^{60}$ and the court concluded that "this is an extremely ordinary happening in a hockey game and the players really think nothing of it."61 The court underscored the cominonness of blows like this one by saying that it occurred during "a skirmish such as any one of a thousand skirmishes that occur during the course of the National Hockey League season."62 There was no allegation that the blow caused any measurable injury.

In Regina $v$. Watson, ${ }^{63}$ the court held that a blow delivered to the shoulder of an opponent while the players were jostling each other in an area directly in front of the goal was not an unlawful assault because players are presumed to consent to such blows. ${ }^{64}$ The court recognized that a lot of jostling ordinarily occurs in the area in front of the goal because the competition for advantageous positions is particularly strong there. ${ }^{65}$ When a lot of jostling is predictable, so is the infliction of minor blows. The blow in this case was not of sufficient force to be audible, ${ }^{66}$ and the only injury to the player struck was a welt on the shoulder that was not shown to be serious. ${ }^{67}$

The fact that players of contact sports are deemed to consent to a variety of minor physical contacts at least partially explains why common assault charges are unlikely to succeed. As the court observed in Regina v. Green:

[G]iven the permissiveness of the game and the risks that the players willingly undertake, $I$ find it difficult to envision a circumstance where

59. [1971] 1 O.R. 591, 594 (Ont. Prov. Ct. 1970).

60. Id.

61. Id.

62. Id. at 443.

63. 26 C.C.C.2d 150 (Ont. Prov. Ct. 1975).

64. Id. at 152-55. Watson, the defendant, was the player who received the blow. He was prosecuted for a subsequent attack on Lundrigan, the player who had struck him in the shoulder with his stick. Watson claimed that he had acted in self-defense, and the validity of this defense depended on the blow by Lundrigan being an unlawful assault. Id. at 155 .

65. Id. at 152.

66. Id. at 153 .

67. Id. There was conflicting testimony as to whether there was a blow at all, or whether the blow caused the welt. Id. at 152-53. 
an offense of common assault as opposed to assault causing actual bodily harm could readily stand on facts produced from the incidents occurring in the course of a hockey game played at [the NHL] level. ${ }^{68}$

\section{b. Players' lack of consent to fights initiated by or against bystand-} ers. In hockey, the inodel situation in which no criminal liability for assaultive acts is imposed involves a cluster of players shoving, pushing, and jostling each other ${ }^{69}$ in an area where the puck is in play. The physical contact is nonspecific, directed against any available opponent. The contact involves no sudden, violently aggressive outbursts. The contact is to some extent justified by the competitive goals of the game, since trying to get near the puck is strategically crucial. ${ }^{70}$ Criminal conviction becoines more likely as the facts diverge froin this pattern. If violence involves deliberate forceful blows in a one-on-one confrontation unrelated to the inain focus of the game, courts are more likely to find that an assault has been committed. ${ }^{71}$

Regina v. Henderson 72 involved an attack on a player whoin the court characterized as "almost in the category of an innocent bystander."73 There had been no overt act by the victim against his attacker at any time before or during the game. The victim was not looking in his assailant's direction at the time of the blow. There was no indication that the victim expected any involvement with his assailant. He was inerely standing by, waiting for play to resume following an alter-

68. Green, [1971] 1 O.R. 591, 597 (Ont. Prov. Ct. 1970).

69. See, e.g., Regina v. Henderson, [1976] 5 W.W.R. 119, 120 (B.C. Co. Ct. 1976) ("pushing, shoving and holding onto one another"); Watson, 26 C.C.C.2d at 152 ("jostling"); R. v. Gray, [1981] 6 W.W.R. 654, 656 (Sask. Prov. Ct. 1981) ("[A]ll of the skaters on the ice, as is common in Canadian hockey, felt compelled to grab an opponent and generally to tug his sweater and clutch and jostle him-to 'waltz around' with him, as this manoeuvre is identified by those who follow hockey.").

70. Arguments that fighting is strategically related to the competitive goals of the game of hockey, based on the premise that fighting intimidates opponents and gives fighters a competitive edge, should be rejected. Hockey can certainly be played without fights. Professional hockey as we know it perhaps cannot be played without fights, but because the reason for societal concern about sports violence is that sports as we know them have gone too far in allowing violent behavior, the objective is precisely to alter the current forms of these sports. See Flakne \& Caplan, supra note 13, at 35 (arguing that nothing short of criminal sanctions will deter hockey violence).

71. The Forbes-Boucha incident, supra note 1, involved facts that fit this pattern closely. Forbes's blow to Boucha came after play had stopped, as both of the players were leaving the penalty box to return to their team benches. See Flakne \& Caplan, supra note 13, at 34. Forbes struck Boucha in the head from behind with his hockey stick. Id. Although there was no conviction in the Forbes trial, the jury was deadlocked 9-3 in favor of conviction. Id. Moreover, the fact that there was a grand jury indictment suggests that in the United States, as in Canada, this sort of attack is unacceptable.

72. [1976] 5 W.W.R. 119 (B.C. Co. Ct. 1976).

73. Id. at 127. 
cation between two other players. ${ }^{74}$ The assailant, who was involved in the altercation that stopped play, delivered the blow in question while one of the linesmen who had broken up the fight was escorting the assailant to the penalty box. ${ }^{75}$ The victim's teammate, by virtue of his involvement in the fight, might have consented to receive some blows, but the uninvolved victim clearly had not. ${ }^{76}$ The blow knocked the victim to the ice unconscious; he was left with a bruise and a laceration requiring stitches and was hospitalized for twenty hours for observation. ${ }^{77}$

In contrast to Henderson, several cases have involved assaults arising from the intervention of a previously uninvolved player in an ongoing fight. In $R$. $v$. Gray, ${ }^{78}$ play had essentially stopped after a fight that started between two opponents grew into a general bout of clutching and josthing among players. Ogenchuk and a teammate both grabbed a member of the opposing team, and began to "waltz around" with him. ${ }^{79}$ Ogenchuk backed out of the threesome when the other two started throwing punches at each other. He then skated ten to twelve feet away from the fighters and stood watching as referees and linesmen broke up the fight. Gray, who had been sitting on his team's bench when the fight started, left the bench and jumped over the boards, skated at full speed straight towards Ogenchuk, straight-armed him in the face and neck, then veered away without breaking his stride to head for the fight in progress. ${ }^{80}$ As im Henderson, the victim was oblivious to the onslaught; he "did not see the accused coming at him from his side, and . . . did not brace himself to take the blow he received." 81 The blow knocked Ogenchuck to the ice; he swallowed his tongue, was rendered unconscious, and was hospitalized for two days for observation..$^{82}$

The Gray fact situation made the case a good one for imposing criminal sanctions. By backing away from the fight, the victim clearly indicated his intention to dissociate himself from it. Since the assailant was not on the ice at all at the time the victim was involved in the scuffle, it is totally implausible to interpret the facts as indicating any consent by the victim to engage in a new fight with the assailant.

There have been convictions of assault causing serious bodily harm in two cases with fact situations related to, but less dramatic than, Gray.

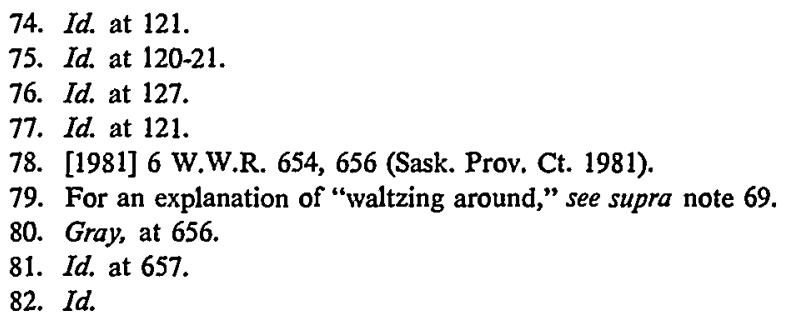


In R. v. Coté, ${ }^{83}$ a player struck an opponent in the abdomen with his stick. While play was stopped for the referee to signal a penalty, a teammate of the player who had been struck dropped his gloves and stick, sped towards the penalized opponent, and punched him in the face. ${ }^{84}$ The victim fell to the ice with a minor facial fracture. ${ }^{85}$ The intrusion of the assailant into the preexisting fight was marginally inore foreseeable here than in Gray, since Cote was on the ice rather than on the players' bench when he launched his assualt. But the attack was still an unjustified, unprovoked, nonconsensual assault.

In Regina v. Watson, ${ }^{86}$ two players had been jostling in front of the home team's goal. As play moved towards the visiting team's goal, the jostling ended, and the visiting player began skating towards his own goal. The opponent with whom he had been jostling dropped his stick and gloves and pursued him. When he caught him, he grabbed the visitor in an armlock around the throat and held on until the visitor became unconscious. Aside from the jostling episode, the visiting player had neither struck his opponent nor made any overtly hostile gesture towards him. ${ }^{87}$ The Watson facts differ from those of Gray and Cote in that both Watson and his victim were involved in the immediately preceding fight with each other. Nonetheless, the victim was in the role of a bystander when Watson attacked him anew. Like the victim in Gray, the Watson victim had signaled his desire to disassociate himself from the fight by moving away. He in no way indicated consent to engage in a renewal of the fight.

\section{B. Consent Implied by Specific Acts.}

The question whether a specific act by one player implies consent to a violent act in response is discussed exphicitly only in Regina v. Watson. In Watson, the court viewed two acts by the victim as furnishing possible support for a finding of implied consent: the victim's minor blow to his subsequent assailant while both players were jostling in the area in front of the loone team's goal, and the victmi's dropping his stick and gloves immediately before he was attacked near the visiting teain's goal. ${ }^{88}$ The court quickly disposed of the argument that either of the victim's actions could imply consent to the force the assailant applied to him ${ }^{89}$-an arm-

\footnotetext{
83. 22 C.R.3d 97 (Que. Prov. Ct. 1981).

84. Id. at 98 .

85. Id. at $98-99$.

86. 26 C.C.C. $2 d 150$ (Ont. Prov. Ct. 1975).

87. Id. at 153.

88. Id. at 157. See supra note 64 .

89. Id. at 157-58.
} 
lock held until the victim became unconscious. ${ }^{90}$ The court recognized that if every player who was hit by a stick could claim that his opponent thereby consented to the application of great force, the hockey arena would be an even more dangerous place. ${ }^{91}$ The victim's dropping his stick and gloves was not a gesture of consent to the assault but rather "the reflexive action of a gentlemanly player recognizing that he was about to be attacked."92

Although the possibility of consent implied by specific acts rather than by general participation in the game is rarely discussed as a separate issue, it seems to underlie the analysis in many cases. This is evident from the detailed summaries of the progress of the game leading up to the assaultive behavior. In Henderson, for example, the court recounted in detail the events leading up to the blow that resulted in the prosecution: the assailant had been involved in a flght with another player that did not include his subsequent victim; no overt act by the victim directed at the assailant had immediately preceded the attack, nor occurred at any other time before or during the game; the victim was not looking in the assailant's direction at the time of the attack, nor was there any indication that the victim expected to become involved with the assailant or receive the blow from him; at the time of the blow, the assailant was skating towards the penalty box, and the victim was stationary. ${ }^{93} \mathrm{Be}-$ cause the victim's participation in the game was not at issue, the recitation of this background to the assault serves no apparent purpose unless the court meant to show that the victim did not, by any act on his part, consent to the blow he received. ${ }^{94}$

\section{Consent as Limited by Public Policy.}

A number of courts have held that, in the sports context as else-

90. Id. at 153.

91. Id. at $157-58$.

92. Id. at 158. This interpretation of a player's dropping his stick is not universally accepted. See, e.g., Flakne \& Caplan, supra note 13, at 34 (arguing that "normal hockey brawling ctiquette calls for the discarding of the [stick] before a fight").

93. Regina v. Henderson, [1976] 5 W.W.R. 119, 120-21 (B.C. Co. Ct. 1976).

94. For a similar analysis, see Regina v. St. Croix, 47 C.C.C.2d 122 (Ont. Co. Ct. 1979). After a scuffe between Shaule and St. Croix, St. Croix accused Shaule of having slashed him across the ankle and having pushed him into the net; words were exchanged, and St. Croix then hit Shaule across the mouth with his stick held horizontally with the hands apart, in a cross-checking position. The court recognized that athletes in all sports consent to "the normal risks of the game and to a foreseeable amount and type of assaults." Id. at 124. This language suggests that the only basis considered for implied consent was participation in the game generally. But the detailed recounting of events leading up to the cross-checking blow on which culpability was premised strongly suggests that the court also considered whether either the alleged ankle-slashing or the alleged push into the goal implied consent to the fore-checking. 
where, public policy does not permit consent to some types of assault.95 A public policy bar to the consent defense was imposed in Regina $v$. Watson. ${ }^{96}$ After liaving inethodically eliminated the possible grounds for a finding that the victim had consented to the attack, the court went on to say that it was doubtful whether the victim could legally consent to such application of force:

If an act is unlawful in the sense of being in itself a criminal act, it is plain that it cannot be rendered lawful because the person to whose detriment it is done consents to it. No person can license another to commit a crime.... As a general rule, although it is a rule to which there are well established exceptions, it is an unlawful act to beat another person with such a degree of violence that the infliction of bodily harm is a probable consequence, and when such an act is proved, consent is immaterial. ${ }^{97}$

The court suggested that a prize fight might be an example of an exception to this general rule, because one object of a prize fight is to render

95. The issue was apparently first raised in Regina v. Maki, [1970] 3 O.R. 780, 783 (Ont. Prov. Ct. 1970) (quoting The Queen v. Coney, 8 Q.B.D. 534, 549 (1882) (Stephen, J.)), where the court said:

In cases where life and linb are exposed to no serious danger in the counnon course of things, I think that consent is a defence to a charge of assault, even when considerable force is used, as, for instance, in cases of wrestling, single-stick, sparring with gloves, football, and the like; but in all cases the question whether consent does or does not take from the application or [sic] force to another its illegal character, is a question of degree depending upon circumstances.

In Coney, three viewers of an illegal prize fight had been convicted of assault by virtue of the aiding and abetting that the trial court said was implied as a matter of law by their presence. Coney, 8 Q.B.D. at 535-36. The Queen's Bench held that the conviction had to be quashed, because the jurors who originally voted for conviction had informed the trial court that they did so solely on the basis of its instruction as to the law. Without the instructions, the jury would not have found aiding and abettiug. Id. at 536. The remarks by Judge Stephen, as quoted by the Maki court, concerned the guilt of the fighters themselves rather than the guilt of the accused spectators whose case was actually before the court; therefore, the remarks were merely dicta. The Coney opinions make it clear that the judges were rejecting the notion that consent to assault by the parties who were striking each other could preclude the Crown from bringing criminal assault charges. Id. at 538 (Cave, J.); id. at 549 (Stephen, J.); id. at 553 (Hawkins, J.). Judge Mathew's opinion in Coney most clearly makes this point:

It was said, that because of the consent of the combatants to fight there could not be an assault .... The contention really meant that the agreement of the men to fight rendered the contest lawful and innocent. There is, however, abundant authority for saying that no consent can render that innoccut which is in fact dangerous.

Id. at 546-47.

The court in Regina v. Maloney, 28 C.C.C.2d 323 (Ont. G.S.P. 1976), also instructed the jury that there were legal limits to the consent a person can give, regardless of express or implied consent, and provided the following example: "For instance, no persons can by agreement go out to fight with deadly weapons doing by agreement what the law says shall not be done and thus shelter themselves from the consequences of their acts." Id. at 327 (quoting Regina v. Bradshaw, 14 Cox C.C. 83, 8485 (Eng. Midland Cir. 1978)).

96. 26 C.C.C. $2 d 150$ (Ont. Prov. Ct. 1975).

97. Id. at $158-59$ (quoting The King v. Donovan, [1934] 2 K.B. 498,507 (Crim. App. 1934)). 
the opponent unconscious. ${ }^{98}$ The court, however, went on to say that because rendering a resisting opponent unconscious through near strangulation is not an object of hockey, hockey games are not an exception to the general rule. ${ }^{99}$ Because the general rule rather than an exception applied in Watson, the victim's consent was immaterial. ${ }^{100}$ In $R$. $v$. Gray, ${ }^{101}$ any consent of the attacked player was also found irrelevant because the court said that the victim cannot consent to use of such force as the assailant applied-a straight-arm blow delivered by a player skating at full speed. ${ }^{102}$

\section{BRIGHT-LINe Tests Defining Assault}

Canadian courts have considered applying three bright-line tests in sports violence cases. One suggested test would draw a bright line between offenses that occur during a game and offenses that occur in a penumbral zone around the game. A second suggested bright line would make the observance or nonobservance of game rules an essential factor in determining liability. A third possible briglit line would distinguish between offenses that occur in professional sports and offenses that occur in amateur sports.

\section{A. The Official Period of Play as Determinative.}

In determining the acceptability of player conduct, the Canadian cases are divided on the effect of the stopping of play. At one extreme, the court in Regina v. Leyte ${ }^{103}$ recognized that the emotional intensity awakened during play may justify conduct that would not be acceptable in calmer situations, and that the effect of this intensity does not wear off as soon as the whistle is blown. This reasoning suggests that the Leyte court would be unwilling to draw a bright line between conduct immediately before and immediately after the referee's whistle. ${ }^{104}$ At the other extreme, the court in Re Duchesnea ${ }^{105}$ considered conduct after the referee's whistle as essentially uninfluenced by the play that preceded it and imposed a much stricter standard on conduct occurring after the whistle. ${ }^{106}$ The courts in Regina v. Henderson ${ }^{107}$ and $R$. v. Gray ${ }^{108}$ took an intermediate position; tliey drew a hine between conduct occurring during

\footnotetext{
98. Id. at 159 .

99. Id.

100. Id.

101. [1981] 6 W.W.R. 654 (Sask. Prov. Ct. 1981).

102. Id. at 656,661 .

103. 13 C.C.C. $2 d 458$ (Ont. Prov. Ct. 1973).

104. For a discussion of this test, see infra notes 110-13 and accompanying text.

105. 7 C.R.3d 70 (Que. Youth Trib. 1978).

106. For a discussion of this test, see infra notes 114-15 and accompanying text.
} 
play and conduct occurring outside of play, but found merely that conduct occurring outside of play can be readily scrutinized to determine whether such conduct was intentional. 109

The Leyte court recognized that players consent to some assaultive conduct that occurs shortly after play is stopped. This tolerance einbraces certain kinds of conduct that occur until there has been a "significant time interval [after] the termination of play ... where the players by their conduct have . . . ceased to be aggressive." 110 Leyte thus drew a line around actual play but added a margin to include additional time after play stopped.

The Leyte opinion is exceptionally short, and the reasons for the court's adoption of this standard are not articulated. In reaching its decision, however, the court considered the judgment in Maki. ${ }^{111}$ Maki only hinted at the importance of whether the alleged assault occurred during actual play. In outlining the facts of the case, the Maki court referred to the incident as having occurred "during the playing" of an NHL exhibition game ${ }^{112}$ but developed the point no further. Maki did, however, approvingly cite language from Agar $v$. Canning to the effect that provocation and the heat of the game could not brimg injuries inflicted with a definite resolve to injure within the scope of implied consent. ${ }^{113} \mathrm{Maki}$ did not make it clear whether the heat of the game should be recognized as a factor only during play or generally in connection with the game; Leyte adopted the latter approach.

The court in Duchesneau was unusually decisive in drawing a bright line between conduct occurring before and conduct occurring after the referee's whistle blows. The court criticized earlier decisions that failed to draw such a line, saying that what happens after the whistle blows is no longer part of the game, even though it often arises out of conduct that occured prior to the whistle. ${ }^{114}$ The court refused to recogirize innplied consent to conduct that occurred after the whistle was blown, saying that once the whistle was blown for the express purpose of signaling to the players the cessation of play, what occurred thereafter was no

107. [1976] 5 W.W.R. 119 (S.C. Co. Ct. 1976).

108. [1981] 6 W.W.R. 654 (Sask. Prov. Ct. 1981).

109. For a discussion of this test, see infra notes 116-22 and accompanying text.

110. Regina v. Leyte, 13 C.C.C.2d 458, 459 (Ont. Prov. Ct. 1973).

11. Id. (acknowledging reliance on Maki, Green, and the unreported case of Regina $y$. Hutchison).

112. Maki, [1970] 3 O.R. at 780.

113. Id. at 783 (quoting Agar v. Canning, 54 W.W.R. 302, 304 (Man. Q.B. 1965), aff'd, 55 W.W.R. 384 (Man. C.A. 1966)).

114. Re Duchesneau, [1979] 7 C.R.3d 70, 83 (Que. Youth Trib. 1978). 
longer hockey. ${ }^{115}$

After stating that altercations "during a hockey game" can occur either "during the actual playing of the game" or "after the play has been stopped for whatever reason by a referee,"116 the court in Henderson went on to apply the same standard for assessing liability in both categories of cases: conduct is not actionable if it is "within the bounds of fair play" and "incidental to the sport."117 The court observed that although more altercations probably occur during actual play than after play has been stopped, stricter scrutiny should be applied to incidents that occur after play has ceased. ${ }^{118}$

In dictum the Henderson court expressed a willingness to judge conduct in light of the whole of the game up to the point where the incident occurred.119 It refused to apply such analysis to the facts before it because regular play had been stopped and there had been a lapse of time. The Henderson dictum suggests a second way in which stopping play can be important: it can cut off a chain of events that could otherwise be considered as a whole.

In Gray the court also discussed the importance of whether the conduct occurred during play. The court distinguished the actions of Green and Maki from those of Gray by pointing out that the Green-Maki altercation occurred while play was under way and both players were trying to gam possession of the puck, whereas Gray acted while play was stopped for a fight; possession of the puck was not an issue. ${ }^{120}$ As in Henderson, the court did not suggest that different standards for assessing behavior correspond to this distinction. The court found the distinction significant, however, because it is easier to deternine whether the apphication of force is deliberate and intentional when play has stopped. ${ }^{121}$ The court came close to adopting the Duchesneau bright-line position when it found that because play had stopped when the incident

115. Id. at 84 .

116. Henderson, [1976] 5 W.W.R. at 123.

117. Id. It would seem that actions occurring after play has stopped would very rarely if ever be incidental to the sport, though since the Henderson court recognized fighting as "part of the game of hockey," id., it obviousiy took a broad view of what that sport involves.

118. Id. The rationale for the stricter scrutiny after play has stopped is that during actual play players may still be caught up in the heat of the game, and their conduct may therefore be instinctive. See id. at 123, 126 (quoting Agar v. Canning, 54 W.W.R. 302, 304 (Man. Q.B. 1965), aff'd, 55 W.L.R. 384 (Man. C.A. 1966)). The court used the timing of the assnult to distinguish Maki and Green, noting that the conduct at issue in those two cases occurred during actual play; it concluded that a stricter standard should be applied in judging Henderson's actions, which occurred after play had been stopped. Id. at 125 .

119. Id. at 126.

120. Gray, [1981] 6 W.W.R. at 659 .

121. Id. 
occurred, Gray's action was not incidental to the game. ${ }^{122}$

Leyte, in recognizing that there will inevitably be some spillover of emotional and physical moinentum after the referee's whistle, presents the preferable rule. Even Duchesneau, the strongest advocate of linedrawimg, recognized that incidents occurring after play has stopped often have their genesis $\mathrm{m}$ game play. Although the bright-line position has the appeal of simphicity, it does not do justice to the complexities inherent in the problem.

\section{B. The Observance of Game Rules as Determinative.}

Another bright line the courts could have drawn is whether the conduct in question violated a rule of the game. This issue has not been treated at length by the Canadian courts. Leyte took the position that players consent to being hit as a result of reactions of other players that are instinctive and closely related to the play, whether or not a foul is being committed. ${ }^{123}$ In contrast, Duchesneau took a strict approach: when play is according to the rules of the game, hockey players consent to siniple assault that occurs during play because otherwise the entire game would have to be outlawed; however, when simple assault is committed or bodily injuries are inflicted by a player in derogation of the rules of the game, there is no consent. ${ }^{124}$ The court in $R$. v. Coté ${ }^{125}$ also advocated a strict approach: criminal charges are appropriate except where the assault is accidental and has been committed without breaking the rules of the game. Similarly, the court in Gray said that violating a game rule imdicates that the conduct giving rise to the violation was deliberate and intentional rather than accidental. ${ }^{126}$

Several courts adopting a test for consent from a civil case, Agar $v$. Canning, ${ }^{127}$ have taken a curious approach to the question of whether players consent to violation of game rules. In Agar, the court said that a player must be held to consent to "an unintentional injury resulting from one of the frequent infractions of the rules of the game."128 This sounds like a broad, inclusive standard. It seems intuitively obvious that players can more reasonably be held to consent to unintentional injuries resulting front conduct within game rules than to unintentional mjuries resulting from infractions.

122. Id. at 661 .

123. Leyte, 13 C.C.C.2d at 459.

124. Duchesneau, [1979] 7 C.R.3d at 83.

125. 22 C.R.3d 97, 101-02 (Que. Prov. Ct. 1981).

126. Gray, [1981] 6 W.W.R. at 658.

127. 54 W.W.R. 302 (Man. Q.B. 1965), aff'd, 55 W.W.R. 384 (Man. C.A. 1966).

128. Id. at 304 . 
The test, however, can best be understood by emphasizing "frequent." Minor infractions, such as a blow with a gloved hand, are more frequent than major mfractions, such as a blow with the hockey stick. If "frequent infractions" are the same as "minor infractions," then the test can be understood as referring to implied consent to minor physical contacts. ${ }^{129}$ The court inay also be saying that it is easier to find consent to frequent infractions because players inore clearly assume the risk of cominon, highly predictable happenings than of very infrequent and unusual ones.

The question whether the conduct violated the rules is closely akin to the question whether the conduct occurred in the course of play. The answers to both questions support or undermine inferences as to whether the conduct was dehiberate and intentional or accidental and whether the victim consented to the conduct. The courts have been correct in refusing to place inuch emphasis on whether or not rules are violated. The state's evaluation of acceptable and unacceptable behavior should not be controlled by the ruleinaking of a private organization.

\section{The Distinction Between Amateur and Professional Play as Determinative.}

The courts have recognized a sliding scale of consent based on whether one is playing professional or annateur sports, but they have not created a bright-line distinction between anateur and professional players. Green einphasized the character of NHL play in discussing the extent of consent to assault, saying that the speed, force, vigor, and competitiveness of NHL hockey inake play without a number of incidents that would be called assaults in other contexts inpossible. ${ }^{130}$ The court's statement that it was difficult to envision a successful prosecution for coinmon assault rather than assault causing bodily harm arising out of a hockey game played at the NHL level suggests a possible bright-line

129. See supra notes 59-68 and accompanying text.

130. Green, [19711 1 O.R. at 594. The reported Canadian cases suggest that convictions of professional players for sports violence are much more likely if trial is by a judge rather than a jury. It seems likely that jurors will find that professional players consent to rougher conduct than do amateurs. These two observations suggest that convictions will be most easily achievable in cases where the player is charged with a misdemeanor (so that the case is tried by a judge rather than by a jury) and in cases involving amateur rather than professional players. These categories will often overlap. Thus, professional players, whose violent conduct is broadcast to the widest audience and who are most readily seen as role models by younsters, will be relatively insulated from criminal conviction. Almost all the reported Canadian cases have been tried to a judge rather than a jury. But see Regina v. Maloney, 28 C.C.C.2d 323 (Ont. G.S.P. 1976) (jury trial). People v. Jones, 37 Ill. App. 3d 879, 346 N.E.2d 389 (1976), was tried to a jury and resulted in conviction. But State v. Forbes, No. 63,280 (Minn. Dist. Ct., 4th Jud. Dist., judgment of mistrial entered, Aug. 12, 1975), resulted in a hung jury. See J. BARNES, supra note 1 , at 104 n.50. 
standard, but the statement is merely dictum and is not further elucidated. ${ }^{131}$

In Regina v. St. Croix, ${ }^{132}$ the court recognized a continuum of levels of hockey play, with a corresponding continuum of consented-to assaults. In deciding the case, the court referred only to Maki and Green, both of which involved NHL players. ${ }^{133}$ Since St. Croix involved a purely amateur friendly neighborhood hockey game, it appeared at the opposite end of the continuum from Maki and Green, and both the level of play and the level of consent were easily distinguishable.

The Duchesneau court pointed out that the game did not mvolve professionals but rather young people playing for their own entertainment. In the court's opinion, however, this fact was of no consequence to the ultimate disposition of the case. ${ }^{134}$ If everything that occurs after the whistle has been blown to end play is no longer a part of the gaine of hockey, then presumably distinctions between professional and amateur play are not relevant.

The courts have acted wisely in recognizing a sliding scale without getting bogged down in articulating bright-line tests to mark the points along that scale. There are many possible gradations in levels of play, and there is no limit to the number of lines that could be drawn. After distinguishing between professional and amateur play, one could distinguish between exhibition gaines, regular season games, and championship games. One could distinguish between organized teams or leagues and spontaneous pick-up matches. The futility of any attempt to clarify the situation by drawing precise lines is evident at the outset, but the need to recognize degrees of difference is equally evident.

\section{CONCLUSION}

There are few grounds for criticizing the general doctrinal development of the Canadian criminal law in the context of sports violence. There have now been enough reported decisions to establish certam hines of analysis as definite inajority positions. Although the general guidelines articulated thus far are not very useful, they nevertheless provide a rough sense of the kinds of actions to which a player consents. Moreover, in deciding how and whether to draw bright lines, Canadian courts have inade progress in clarifying when the special standards they have developed for imposing criminal hability in the context of sports violence

131. Green, [1971] 1 O.R. at 597.

132. 47 C.C.C.2d 122 (Ont. Co. Ct. 1979).

133. Id. at 124. Defense counsel had also called the court's attention to Leyte, a handball case, but the court apparently considered the hockey cases more valid as precedents.

134. Duchesneau, [1979] 7 C.R.3d at 84. 
should be applied. The Canadian experience illustrates that federal legislation, such as the proposed Sports Violence Act, may not be necessary.

The Canadian system, however, has an initial advantage over that of the United States because the Criminal Code of Canada supplies a single definition for the entire nation of the offenses at issue. This avoids the problem of forcing players who compete in various jurisdictions to adjust their conduct to conform to varying standards. Applying this single nationwide statutory definition, Canadian courts have developed a modest set of doctrines for dealing with offenses in a single sport, hockey. If state courts in the United States are to develop doctrines for not only hockey but also football, and potentially basketball and baseball, either the increased burden in terms of case load will be ininense, or the time involved to develop lines of decisions will be internninable.

In evaluating the desirability of increased criminal prosecution of sports violence offenses in the United States, it is useful to think again about the reasons why we want to decrease the incidence of sports violence and about alternative means available for achieving that goal. Insofar as the inain reason is to discourage violence for the sake of the players exposed to that violence, use of the criminal law is certainly appropriate, although it may result in stricter sanctions than would be most desirable. But if the main reason is that seeing violence on the ice or the playing field inay set a bad example for spectators or for people who view professional athletes as role models, the criminal law may not be appropriate.

Nevertheless, the criminal law has a place in dealing with sports violence. Self-regulation of professional sports leagues is irrelevant to violence on amateur playing fields. Although tort actions nay protect the rights of individual hitigants, they do not adequately protect the state's interests. Neither application of the criminal law nor any of the other proposed methods for dealing with sports violence will, alone, adequately address all aspects of the problem. But in the meantine, American courts inust deal with criminal charges that are brought against both ainateur and professional athletes. The Canadian experience shows that there can be convictions for sports violence; Ainerican case law can develop the necessary doctrines from existing offenses without new legislation. The most enlightening aspect of the Canadian cases is not that they present a radical new approach that makes adjudication of sports violence offenses possible. It is, instead, that the cases demonstrate the feasibility of usimg tráditional analytic approaches to deal with what initially presents itself as an unusual problem.

Diane $V$. White 